\title{
Editorial
}

\section{Food and Non-Food Biomass Production, Processing and Use in sub-Saharan Africa: Towards a Regional Bioeconomy}

\author{
Daniel Callo-Concha * $\mathbb{D}^{\mathbb{D}}$, Hannah Jaenicke, Christine B. Schmitt ${ }^{\circledR}$ and Manfred Denich \\ Center for Development Research (ZEF), University of Bonn, 53113 Bonn, Germany; \\ h.jaenicke@uni-bonn.de (H.J.); cschmitt@uni-bonn.de (C.B.S.); m.denich@uni-bonn.de (M.D.) \\ * Correspondence: d.callo-concha@uni-bonn.de; Tel.: +49-228-731795
}

Received: 2 March 2020; Accepted: 4 March 2020; Published: 6 March 2020

\begin{abstract}
The bioeconomy concept has the aim of adding sustainability to the production, transformation and trade of biological goods. Though taken up throughout the world, the development of national bioeconomies is uneven, especially in the global South, where major challenges exist in Sub-Saharan Africa with respect to implementation. The BiomassWeb project aims to underpin the bioeconomy concept by applying the 'value web' approach, which seeks to uncover complex interlinked value webs instead of linear value chains. The project also aimed to develop intervention options to strengthen and optimize the synergies and trade-offs among different value chains. The special issue "Advances in Food and Non-Food Biomass Production, Processing and Use in Sub-Saharan Africa: Towards a Basis for a Regional Bioeconomy" compiles 22 articles produced in this framework. The articles are grouped in four sections: the value web approach; the production side; processing, transformation and trade; and global views. The synthesis presented in this paper introduces the challenges of the African bioeconomy and the value web approach, and outlines the contributing articles.
\end{abstract}

Keywords: Biomass-based value web; biological goods; bio-based economy; food and non-food; circular economy

\section{Introduction}

\subsection{The Sub-Saharan African Biomass Sector}

The rising global demand for biomass as food, feed, industrial raw material, and a source of energy is putting increasing pressure on the agricultural sector. This is particularly true for Sub-Saharan Africa (SSA), where many countries are confronted with growing regional and global demands for biomass-derived products while not yet having solved their national demands for food and non-food biomass [1-5].

Though food and nutrition security has improved globally in the last few decades, around $30 \%$ of the population in SSA is still faced with various forms of food insecurity. The number of undernourished in SSA has risen from 177 million in 2005 to 237 million in 2017 [5]. Associated indicators, such as the rates of anemia in women of reproductive age and stunting and wasting in children under the age of five, have increased [6,7]. With regard to energy supply, the major source of domestic fuel in SSA is fuelwood, which is primarily collected from forests, woodlands, and parklands. Due to rapid urbanization and a lack of alternatives, fuelwood is in demand not only in rural but also in urban areas, where up to $90 \%$ of households depend on it. With an average consumption of 1 $\mathrm{kg}$ fuelwood per person and day and a population of one billion people with an annual growth rate 
between $3 \%$ and $4 \%$, the 'fuelwood gap' remains an ecological and socioeconomic challenge [8-11]. In SSA, modern biomass processing is still in an early stage, and the production of food is not harmonized with the production of biomass-based raw materials. This was evidenced during the recent boom of the biofuel industry that attracted governments to promote the large-scale cultivation of oil palm, jatropha, cassava, and sugarcane despite warnings about the risks of competition for land [12-16].

Many of these matters are rooted in the agricultural sector, which is the focus of this special issue. Farming in SSA falls roughly into two major categories: (i) subsistence or semi-subsistence farming by smallholders to cover their own demands and to market surpluses, and (ii) commercial farming managed by estates, large enterprises, emerging medium-size farms, or organized small farmers under government programs (contract farming), many of which are devoted to producing export-oriented crops, such as cotton, coffee, cocoa, flowers or vegetables [17,18]. Both categories face challenges that hamper and limit their development. While subsistence farming is severely limited by rural poverty, institutional and technical weaknesses, ecological fragility (aggravated by climate change), and political instability [19-21], commercial farms, by their economic focus, have been accused of undermining environmental and social standards, and they are challenged by the volatility of international prices due to their dependence on external markets [22].

\subsection{Challenges for an African Bioeconomy}

Bioeconomy, or bio-based economy, is defined as the " ... knowledge-based production and use of biological resources to provide products, processes and services in all economic sectors within the frame of a sustainable economic system." It is based on the expectation of expanding biomass production and processing sectors going beyond the production of food, feed, fiber, fuel, and other basic products towards the production of value-added goods and services that are demanded by other economic sectors such as the industry, energy, pharmacy, and chemical sectors [16].

A biomass-based economy is increasingly envisaged by many countries as a path to follow. While most countries of the global North are investigating and developing new technologies, establishing large and sophisticated biorefineries, focusing on maximizing benefits, minimizing waste, and even reorganizing their institutions accordingly, progress in the global South is limited ([23-25] in this special issue).

In most regions of SSA, biophysical features such as the wide availability of productive land and a constant solar radiation are the major comparative advantages for biomass production, and they represent a great natural potential to increase the amount of biomass that is used for food and industrial raw material (non-food, including energy). Nonetheless, currently, only $15 \%$ of the net primary production (NPP) of the continent is used (human appropriation of net primary production-HANPP), and the growth rates of this use are much lower than population growth [26,27]. In Europe, for instance, $35 \%$ of the NPP is appropriated by humans. Accordingly, there are compelling opportunities for SSA's further development based on the more intensive production and use of biomass in the context of a comprehensive African bioeconomy. On the other hand, major challenges for a regional bioeconomy are the weak economic, technical, and institutional conditions that restrain the production, post-harvest and processing sectors. The extent and diversity of these challenges and the pressure on SAA countries to catch up with global trends require diversified strategies and coordinated actions to simultaneously handle these challenges [16,28-30].

A broad consensus is that an African bioeconomy agenda should prioritize (i) the encouragement and enhancement of the productive sector under the premises of ecological sustainability, social equity, and fair economic return to farmers; (ii) the further development of the processing sector by generating, promoting, and adopting innovations, technologies, and techniques to convert biomass into goods of higher value; and (iii) linking producers with processors and with local, national, and international markets to guarantee reliable incomes [16]. 


\subsection{Biomass-based Value Web Approach}

In the context of an emerging African bioeconomy, the project "Improving food security in Africa through increased system productivity of biomass-based value webs (BiomassWeb)" aimed at understanding and enhancing food and non-food biomass production, processing, and trade in Ghana, Nigeria, and Ethiopia. These countries were chosen because of their regional importance and potential as case studies with relevance to other SSA countries. The key crops considered were maize, cassava, plantain/banana/enset, and bamboo, which were selected according to their regional relevance as sources of food and non-food biomass.

The overarching concept was that of the 'biomass-based value webs', i.e., complex systems of interlinked value chains in which biomass products and by-products are produced, processed, traded, and consumed (Figure 1). Though introduced two decades ago [31,32], the value web approach is still innovative, as it more realistically describes the value that is added in the biomass sector in comparison to the linear supply and value chain concepts. Value webs not only depict material and cash flows, they also connect supply and value chains with their actors, e.g., through information flows, the effects of policy decisions, or innovative developments in the production and processing of biomass, as well as via the effects of national and international market events. The resulting dynamic, hyper-connected, and collaborative relationships are country- and situation-specific and can only be disclosed in cooperation with local stakeholders and experts. We argue that the value web is a useful scientific approach for investigating SSA biomass-related activities in view of its current and forthcoming challenges.

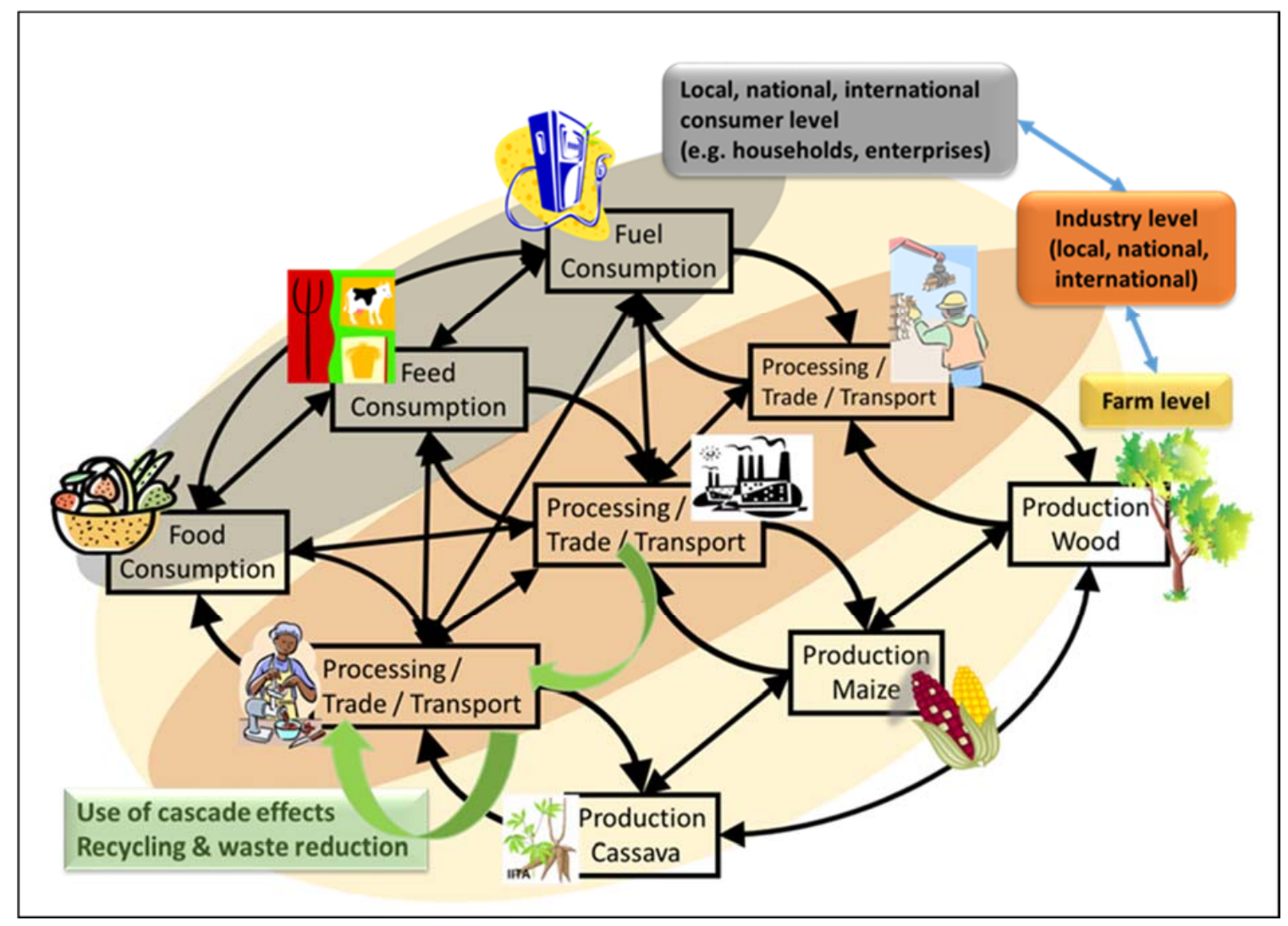

Figure 1. Interactions, trade-offs, and synergies in a biomass-based value web (schematic) [33].

The BiomassWeb project objectives were: (i) to investigate the potential interventions to strengthen biomass value web production, processing and trade, and (ii) to identify the synergies and trade-offs among them. Along this process, BiomassWeb had a strong foresight character in identifying and facilitating the current and future synergies and trade-offs among biomass uses. 
BiomassWeb was co-led by the Center for Development Research (ZEF) of the University of Bonn and the Forum for Agricultural Research in Africa (FARA). The consortium included a network of universities, national research institutions, international agricultural research organizations, and partners from the private sector in Ghana, Nigeria, Ethiopia, and Germany.

\section{Summary of Articles Included in this Special Issue}

This special issue summarizes some of the results of the BiomassWeb project, together with other selected research results regarding exploring, developing, and testing innovative approaches to produce, process, and trade food and non-food biomass in SSA.

The 22 articles in this volume cover stand-alone and aggregated studies, disciplinary, inter- and transdisciplinary approaches, and ex-post and foresight-oriented investigations. They are compiled into four major sections: (i) overarching studies contributing to the value web approach; (ii) the production side; (iii) processing, transformation and trade; and (iv) the global view.

\subsection{The Value Web Approach}

A few articles are featured that look at the value web approach itself from different perspectives: (i) complex systems analysis, (ii) as the basis for analyzing a supply chain, and (iii) describing a demand-driven research and development concept to identify potential interventions to strengthen the effectiveness and efficiency of biomass-based value webs.

Concerning food security, Anderson et al. model and analyze biomass-based value webs of selected crops in Ghana, Nigeria, and Ethiopia by applying the systems analysis software iMODELER in participatory stakeholder workshops. In all three countries, the transdisciplinary mapping of the different crop-value chains clearly reveals widely ramified systems with a complex web character having food security as the overall target. In contrast to the initial hypothesis, the value chains of the different crops considered do not show relevant direct links between each other in their matter and capital flows. However, they are connected through nonspecific factors (corresponds to nodes or variables in other systems approaches) such as communication, governmental interventions, extension services, agricultural innovations, global food prices, and others. Results from a generic model allow for a critical reflection on the relation between value web dynamics and food security policy in SSA. Current policy-making trends targeting the market integration, mechanization, and reduction of post-harvest losses are supported by the model results.

In a case study, Lin et al. focus on the current market challenges and opportunities for the future development of the northern Ethiopian bamboo producing and processing sectors. The results show that bamboo producers are constrained by the lack of local demand and markets for higher-value bamboo products. This also leads to less product diversification on the local markets and reduces the innovative capacity of the manufacturing sector. It is recommended that local and regional governments support specific training programs on bamboo production and processing. Additionally, the market access of small bamboo producers may be improved through the establishment of cooperatives and the development of contractual arrangements that protect local producers, processors, and traders.

A demand-driven research and development (DDRD) program was one of the innovative aspects of the BiomassWeb project. Funds were provided by the donor agency for implementing research and development activities that emerged from alliances with stakeholders of the biomass producing, processing and trading sectors during the project lifetime. Jatta et al. discuss the concept and application of DDRD in Ghana, Nigeria, and Ethiopia based on six projects that were selected and supervised by the Forum for Agricultural Research in Africa (FARA): (i) using cassava peels for mushroom production, (ii) the development of plantain biomass into composite flour for traditional foods and bakery products, (iii) bamboo leaves as fodder for livestock production, (iv) the production of bio-plastics and bio-gels from agricultural waste, (v) the mass and energy balance analysis of pneumatic dryers for cassava, and (vi) exploring potentials of the bamboo sector for employment and food security. 


\subsection{The Production Side}

The contributions in this section cover a broad array of biomass-based production systems and highlight the need to tackle food insecurity by using a variety of approaches.

Several studies focus on smallholder crop production systems. Scheiterle and Birner show that in Ghana, maize production systems with above-average yields of $1.5 \mathrm{Mt} / \mathrm{ha}$ are profitable at the household level, while production systems below this threshold report negative social profits. The use of fertilizers that are sponsored through national subsidies, however, does not increase the likelihood to produce above-average yields, while the use of improved seeds and herbicides does. For Ethiopia, Srivastava et al. employ a modelling approach to test the effect of different intensification scenarios on maize yields. They report that a combination of higher mineral fertilizer rates and the incorporation of crop residues are the most successful, while the rotation of maize with groundnut could help to increase economic profits. Legesse et al. use a modelling framework to evaluate the effects of a higher efficiency of fertilizer application in a variety of cropping systems in Ethiopia. Higher fertilizer application increases annual yields at the average farm and is profitable despite a price reduction on the markets, which has a positive effect on the welfare gains for both rural farming and non-farming households. Finally, Poku et al. show that in the case of cassava outgrower schemes in Ghana, contract farming could benefit both farmers and agribusiness firms if contracts sustained long-term supportive business agreements.

Next to field cropping systems, agroforestry systems can make a strong contribution to food security through food and non-food biomass production. For Ethiopia, Jemal et al. demonstrate that smallholder farmers can benefit from 120 plant species that grow in home gardens, in multistory coffee systems, and in farmland systems with multipurpose trees. Similarly, Kelboro and Stellmacher underline that family farms in Ethiopia rely on ad-hoc agricultural production systems to achieve food security at the household level, and this needs to be taken into consideration when developing agricultural intensification schemes. In Ghana, Akoto et al. assess the local acceptance of bamboo use in agroforestry systems in a dry forest zone. They show that farmers who have traditional knowledge of multipurpose trees and bamboo are more inclined to adopt these systems for combined charcoal, fodder leaf, and crop production. By using a transdisciplinary approach, Mbeche et al. analyze the application of the push-pull technology in Ethiopia to control stemborer pests and Striga weed in maize and demonstrate that transdisciplinary approaches can be efficient in tackling real-life problems.

Moving from the rural to the urban setting, Nero et al. demonstrate the potential of food trees in Accra, Ghana, to contribute to food security in African cities. They report that the diversity of tree species with food uses is higher in poorer neighborhoods than in wealthier neighborhoods, but their abundance is lower in the former than in the latter. They conclude that policies to promote food trees can support several goals, such as achieving food security and raising the quality of living.

\subsection{Processing, Transformation and Trade}

Processing, transformation, and trade are important elements of the biomass-based value web. Several articles explore opportunities and also challenges of the conversion of by-products or waste into valuable products.

Loos et al. apply participatory methods, expert interviews and group discussions to evaluate the potential of plantain residues as a resource for industrial raw materials (fiber) in Ghana. They report that key stakeholders and structures exist that could boost the establishment of a sustainable plantain-based value web. However, pilot activities and technology transfer of suitable innovations from other countries would be required.

In their article, Chala et al. explore the potential of by-products from coffee processing (husk, pulp and mucilage) for biogas production in Ethiopia. The authors estimate that the anaerobic digestion of these products could generate as much as $68 \times 10^{6} \mathrm{~m}^{3}$ methane per year, which could be converted into 238,000 MWh of electricity and 273,000 MWh of thermal energy. Both electricity and thermal 
energy are used by coffee processing facilities and, accordingly, biogas production would lead to energy cost savings.

Intani et al. take a critical look into the use of corncob biochar, which is a sought-after resource for soil amendment. As phytotoxicity has been observed, the experiments carried out by the authors demonstrate that the phytotoxicity of fresh corncob biochar can be effectively mitigated by washing and heat treatments.

Several articles address production and use of cassava and its processing by-products. Ayetigbo et al. provide a review in which they compare properties of cassava root, flour, and starch from white-flesh and biofortified yellow-flesh variants. The companion papers by Adeyemo and Okoruwa on the effects of value addition on the productivity of cassava farming households and by Adeyemo et al. on determinants of the intensity of cassava utilization-both in Nigeria-demonstrate that the prospect of adding value through processing determines production decisions. Better extension services, training, and enterprise regulation, as well as asset acquisition, improving land quality, and the encouragement of social capital development among smallholders, are important drivers.

Looking at waste management options amongst cassava processors in Nigeria, Omilani et al. report that public expenditure on training for processors in waste management options would empower them to use solid-waste conversion technologies to generate value-added products. Besides generating additional income, this would lead to social benefits including a lower exposure to environmental toxins from the air, streams, and groundwater.

\subsection{Global Views}

This section offers a global view on the trends, challenges, and opportunities that countries are confronted with when developing their own bioeconomies.

Given the countries' differences in potential, priority setting and strategies to develop their own bioeconomies, Biber-Freudenberger et al. propose a classification and then sort them into primary, advanced, high-tech, and mixed categories that they later use to gauge their performance in terms of sustainability. The authors find that countries with more sophisticated bioeconomies are more diversified in terms of innovations and policies that promote them. In contrast, countries with incipient bioeconomies are based on less varied alternatives and concentrate on bioenergy, but they tend to explore and expand towards high-tech strategies. Interestingly, the efforts of the former are not necessarily accompanied by more sustainable performance.

One step ahead, Beuchelt and Nassl, under the premise of the UN Sustainable Development Goals that suggest the satisfaction of multiple demands instead of the optimization of a single or a few of them, model the trends of several bioeconomy operation plans and their weighing of economic sectors. They report a worrying imbalance that tends to prioritize the uses of biomass for the generation of energy at the expense of other material uses and even the satisfaction of basic needs like food production.

Finally, Dietz et al. examine the governance strategies of the 41 countries that lead the progression into a biomass-based economy. Contextualizing their analysis into the UN Sustainable Development Goals, they identify four potential pathways and foresee sets of governance measures to enable or constrain their development. Based on the unevenness of outcomes, the authors conclude that advocating for the establishment of political structures (when nonexistent) to put national bioeconomies into operation and for the creation of global frameworks to coordinate and guarantee the sustainability of these structures are key issues.

\section{Concluding Remarks and Outlook}

To date, only a few national or regional strategies for innovative uses of biomass in Africa exist. The papers in this special issue underpin the fact that there is great potential for food and non-food biomass production, use, and trade in Africa. These may encompass production systems, such as bamboo intercropping, underutilized plant species in agroforestry systems, and fruit trees in urban settings, as well as processing techniques, e.g., biochar production, starch uses, and agricultural 
residues as industrial raw materials or energy sources. It clearly appears that further research is needed on implementing the findings in practice, while the results and thoughts that are presented by the authors of this volume already make a contribution to this process.

Additional efforts, however, are needed to disseminate the results to practitioners and thus to contribute to rural development. In general, targeted biomass-related policies and governance measures at the local and national levels, also considering the UN Sustainable Development Goals (SDGs), are recommended to support efforts to help achieve food security and improved quality of living. In particular, rural policies should focus on extension services as well as capacity building and training for biomass producers, processors, and traders. Furthermore, market opportunities and access to markets, in combination with the establishment of cooperatives, have to be developed. Other recommendations for promoting a biomass-based economy range from enterprise regulations, asset acquisition, and contractual issues to social capital development in rural environments.

The examples show that the establishment of biomass-based economies faces a multitude of challenges. The dilemma is that the respective research-based recommendations-as can be seen above-are of a general nature. The implementation of research outputs in practice, however, requires more detailed instructions for action. These can only be developed through systematic implementation research that is transdisciplinary in nature and, accordingly, based on stakeholder involvement. Implementation research aims to identify and overcome the barriers to the implementation of research outputs. Its activities can of course be considerably reduced if newly developed concepts and technologies to be implemented are based on demand-driven research.

Implementation research is the basis for the piloting and up-scaling of innovations based on research and development. In the case of biomass-based innovations, their implementation should take place in the context of a circular bioeconomy. The integration of biomass production, processing, and trade into a circular system requires that value chains of food and non-food biomass and the value webs that are derived from them are analyzed in their system context. Particular attention must be paid to cause-and-effect relationships between the system components. Knowledge of these relationships helps to identify intervention options that contribute to optimizing effectiveness and efficiency of value chains and webs in the biomass sector. Additionally, the meaningful implementation research should consider not only economic, socio-cultural and technical aspects but also aspects such as political structures or the personal resources and capacities of the members of the target groups.

Last but not least, when developing a regional bioeconomy, it must be borne in mind that the nation states concerned have their own policy priorities and strategies that face different development trends, challenges and potentials. Accordingly, different information needs must be met, for which an efficient science communication system has to be established. In this context, the interactive online expert network BiomassNet (https://www.biomassnet.org/) provides a forum for information exchange on biomass-related aspects in Africa.

Funding: This research was funded by the German Federal Ministry of Education and Research (BMBF) and Ministry for Economic Cooperation and Development (BMZ), grant numbers FKZ 031A258A-I.

Conflicts of Interest: The authors declare no conflict of interest.

\section{References}

1. FAO. Biofuels: Prospects Risks and Opportunities. In The State of Food and Agriculture 2008; United Nations Food and Agriculture Organization: Rome, Italy, 2008. [CrossRef]

2. FAO High-Level Expert Forum. Global Agriculture towards 2050. United Nations Food and Agriculture Organization 2009. Available online: http://www.fao.org/fileadmin/templates/wsfs/docs/Issues_papers/ HLEF2050_Global_Agriculture.pdf (accessed on 11 July 2019).

3. Alexandratos, N.; Bruinsma, J. World Agriculture towards 2030/2050: The 2012 Revision. United Nations Food and Agriculture Organization. 2012. Available online: http://www.fao.org/3/a-ap106e.pdf (accessed on 11 July 2019). 
4. van Ittersum, M.K.; van Bussel, L.G.J.; Wolf, J.; Grassini, P.; van Wart, J.; Guilpart, N.; Claessens, L.; de Groot, H.; Wiebe, K.; Mason-D'Croz, D.; et al. Can Sub-Saharan Africa Feed Itself? Proc. Natl. Acad. Sci. 2016, 113, 14964-14969. [CrossRef] [PubMed]

5. FAO, IFAD, UNICEF, WFP and WHO. The State of Food Security and Nutrition in the World 2018. Building climate resilience for food security and nutrition. Rome, FAO. Available online: http://www.fao.org/3/ i9553en/i9553en.pdf (accessed on 11 July 2019).

6. Leathers, H.D.; Foster, P. The World Food Problem: Toward Understanding and Ending Undernutrition in the Developing World; Lynn Rienner Publishers: Boulder, CO, USA, 2017; ISBN-13: 978-1626374515.

7. FAO Statistical Pocketbook 2015: World Food and Agriculture; Food and Agriculture Organization of the United Nations: Rome, Italy, 2015. Available online: http://www.fao.org/3/a-i4691e.pdf (accessed on 11 July 2019).

8. Ouedraogo, B. Household Energy Preferences for Cooking in Urban Ouagadougou, Burkina Faso. Energy Policy 2006, 34, 3787-3795. [CrossRef]

9. Hiemstra-van der Horst, G.; Hovorka, A.J. Fuelwood: The 'Other' Renewable Energy Source for Africa? Biomass Bioenergy 2009, 33, 1605-1616. [CrossRef]

10. Konare, S.; Ninomya, I.; Kobayashi, O.; Shimamura, T. Rural Community Perception of Fuelwood Usage by Families Living in Wassorola, Mali: Interview with Women as Main Fuelwood Collectors. J. Agri. Crop Res. 2013, 1, 76-83.

11. Callo-Concha, D.; Harou, L.; Krings, L.; Ngonjock, J.; Ziemacki, J. Ziemacki. Farming Adaptation in the Western Sudanese Savannah: Lessons Learnt and Challenges Ahead. In Advancing Climate Change Research in West Africa. Trends, Impacts, Vulnerability, Resilience, Adaptation and Sustainability Issues; Kokoye, S., Yegmebey, R., Awoye, O., Eds.; Nova Publishers: Harpark, NY, USA, 2019; pp. 95-131.

12. Gnansounou, E.; Panichelli, L.; Villegas, J.D. Sustainable Liquid Biofuels for Transport: The Context of the Southern Africa Development Community. 2007. Available online: https:/infoscience.epfl.ch/record/121498/ files/Sustainable_Liquid_Biofuels_for_Transport-SADC.pdf (accessed on 11 July 2019).

13. Amigun, B.; Musango, J.K.; Stafford, W. Biofuels and Sustainability in Africa. Renew. Sust. Energ. Rev. 2011, 15, 1360-1372. [CrossRef]

14. van Zyl, W.H.; Chimphango, A.F.A.; den Haan, R.; Görgens, J.F.; Chirwa, P.W.C. Next-Generation Cellulosic Ethanol Technologies and Their Contribution to a Sustainable Africa. Interface Focus 2011, 1, $196-211$. [CrossRef] [PubMed]

15. Popp, J.; Lakner, Z.; Harangi-Rákos, M.; Fári, M. The Effect of Bioenergy Expansion: Food, Energy, and Environment. Renew. Sust. Energ. Rev. 2014, 32, 559-578. [CrossRef]

16. Bioeconomy Council. Global Bioeconomy Summit 2018; Conference Report; Federal Ministry for Education and Research: Bonn, Germany, 2018; Available online: www.gbs2018.com (accessed on 11 July 2019).

17. Porter, G.; Phillips-Howard, K. Comparing Contracts: An Evaluation of Contract Farming Schemes in Africa. World Dev. 1997, 25, 227-238. [CrossRef]

18. Hall, R.; Scoones, I.; Tsikata, D. Plantations, Outgrowers and Commercial Farming in Africa: Agricultural Commercialisation and Implications for Agrarian Change. J. Peasant Stud. 2017, 44, 515-537. [CrossRef]

19. Challinor, A.; Wheeler, T.; Garforth, C.; Craufurd, P.; Kassam, A. Assessing the Vulnerability of Food Crop Systems in Africa to Climate Change. Clim. Chang. 2007, 83, 381-399. [CrossRef]

20. Morris, M.; Binswanger, H.; Byerlee, D.; Savanti, P.; Staatz, J. Awakening Africa's Sleeping Giant: Prospects for Commercial Agriculture in the Guinea Savannah Zone and Beyond; The World Bank: Washington, DC, USA, 2009; ISBN-13: 978-0821379417.

21. Callo-Concha, D.; Gaiser, T.; Webber, H.; Tischbein, B.; Müller, M.; Ewert, F. Farming in the West African Sudan Savanna: Insights in the Context of Climate Change. Afr. J. Agric. Res. 2013, 8, 4693-4705. [CrossRef]

22. von Braun, J.; Tadesse, G. Food Security, Commodity Price Volatility, and the Poor. In Institutions and Comparative Economic Development; Aoki, M., Kuran, T., Roland, G., Eds.; International Economic Association Series; Palgrave Macmillan: London, UK, 2012; pp. 298-312. [CrossRef]

23. Aguilar, A.; Wohlgemuth, R.; Twardowski, T. Perspectives on Bioeconomy. N. Biotechnol. 2018, 40, 181-184. [CrossRef] [PubMed]

24. Dietz, T.; Börner, J.; Förster, J.J.; von Braun, J. Governance of the Bioeconomy: A Global Comparative Study of National Bioeconomy Strategies. Sustainability 2018, 10, 3190. [CrossRef]

25. Biber-Freudenberger, L.; Kumar, B.A.; Bruckner, M.; Börner, J. Sustainability Performance of National Bio-Economies. Sustainability 2018, 10, 2705. [CrossRef] 
26. Krausmann, F.; Erb, K.-H.; Gingrich, S.; Lauk, C.; Haberl, H. Global patterns of socioeconomic biomass flows in the year 2000: A comprehensive assessment of supply, consumption and constraints. Ecol. Econ. 2008, 65, 471-487. [CrossRef]

27. Krausmann, F.; Erb, K.-H.; Gingrich, S.; Haberl, H.; Bondeau, A.; Gaube, V.; Lauk, C.; Plutzar, C.; Searchinger, T.D. Global human appropriation of net primary production doubled in the 20th century. PNAS 2013, 110, 10324-10329. [CrossRef] [PubMed]

28. El-Chichakli, B.; von Braun, J.; Lang, C.; Barben, D.; Philp, J. Policy: Five Cornerstones of a Global Bioeconomy. Nat. News 2016, 535, 221-223. [CrossRef] [PubMed]

29. Virchow, D.; Beuchelt, T.D.; Kuhn, A.; Denich, M. Biomass-Based Value Webs: A Novel Perspective for Emerging Bioeconomies in Sub-Saharan Africa. In Technological and Institutional Innovations for Marginalized Smallholders in Agricultural Development; Gatzweiler, F., von Braun, J., Eds.; Springer: Berlin, Germany, 2016; ISBN 978-3-319-25718-1.

30. Virgin, I.; Morris, E.J. (Eds.) Creating Sustainable Bioeconomies-The bioscience revolution in Europe and Africa; Routledge: London, UK; New York, NY, USA, 2017; ISBN 978-1-138-81853-8.

31. Stabell, C.B.; Fjeldstad, O.D. Configuring value for competitive advantage: on chains, shops, and networks. Strateg. Manag. J. 1998, 19, 413-437. [CrossRef]

32. Smith, R.W.; Broxterman, W.E.; Murad, D.S. Understanding Value Webs as a New Business Modeling Tool: Capturing \& Creating Value in Adhesives; The Adhesive \& Sealant Council: Las Vegas, NV, USA, 2000.

33. Virchow, D.; Beuchelt, T.; Denich, M.; Loos, T.K.; Hoppe, M.; Kuhn, A. The value web approach-so that the South can also benefit from the bioeconomy. Rural 2014, 21, 3.

(C) 2020 by the authors. Licensee MDPI, Basel, Switzerland. This article is an open access article distributed under the terms and conditions of the Creative Commons Attribution (CC BY) license (http://creativecommons.org/licenses/by/4.0/). 